\title{
One Belt One Road Initiative of China: Implication for Future of Global Development
}

\author{
Md Nazirul Islam Sarker ${ }^{1 *}$, Md Altab Hossin², \\ Xiaohua Yin ${ }^{3}$, Md Kamruzzaman Sarkar4 \\ ${ }^{1}$ School of Public Administration, Sichuan University, Chengdu, China \\ ${ }^{2}$ Department of Information Management and Ecommerce, University of Electronic Science and Technology of China, Chengdu, \\ China \\ ${ }^{3}$ School of Automation Engineering, University of Electronic Science and Technology of China, Chengdu, China \\ ${ }^{4}$ Department of Zoology, National University, Gazipur, Bangladesh \\ Email: *sarker.scu@yahoo.com
}

How to cite this paper: Sarker, M.N.I., Hossin, M.A., Yin, X.H. and Sarkar, M.K. (2018) One Belt One Road Initiative of China: Implication for Future of Global Development. Modern Economy, 9, 623-638. https://doi.org/10.4236/me.2018.94040

Received: February 3, 2018

Accepted: April 15, 2018

Published: April 18, 2018

Copyright (C) 2018 by authors and Scientific Research Publishing Inc. This work is licensed under the Creative Commons Attribution International License (CC BY 4.0).

http://creativecommons.org/licenses/by/4.0/

cc) (i) Open Access

\begin{abstract}
One Belt One Road (OBOR) initiative is a historical initiative which connects the people over the world and facilitates various opportunities for global peace. The main purpose of this study is to explore implication of One Belt One Road initiative for global future development. It also analyzes the reasons of origin, strategy, opportunities and challenges of OBOR initiatives on the basis of business, economic, political, social and environmental aspects. This study uses qualitative approach and secondary data particularly journal articles, conference proceedings, various documents of government, books, newspaper articles, magazine articles, and various websites of internet have been extensively used to determine the objectives. This article argues that partner countries and agencies will get economic and political benefits from these initiatives. It facilitates to connect people through road ways, air ways and water ways, coordinating policies of various governments, financial integration through cross border business, productivity and regional energy security. This study also analyzes risks and challenges associated to OBOR initiative implementation. It suggests that strong coordination among partners of OBOR is necessary to get full fruits of OBOR through supportive law, policy, rules and regulations, proper strategy implementation, transparent procurement system, sincere consideration on political, financial, environmental and social factors.
\end{abstract}

\section{Keywords}

OBOR, Economic Corridor, Financial Integration, Global Economic Development, China 


\section{Introduction}

The One Belt One Road (OBOR) initiative was proposed by Chinese President $\mathrm{Xi}$ Jinping in 2013. It is a historical initiative of China to connect the people all over the world. Recently it is known as Belt and Road Initiative. It comprises two major programs entitled to Silk Road Economic Belt and $21^{\text {st }}$ Century Maritime Silk Road. The Silk Road Economic Belt connects three major routes like China to Europe, the Persian Gulf, the Mediterranean and the Indian Ocean, while the $21^{\text {st }}$ Century Maritime Silk Road is based on waterways among member countries of OBOR initiative [1]. It comprises about 65 countries and 900 projects with an investment volume of 850 billion dollars [2]. The Asian Infrastructure Investment Bank (AIIB) was launched with its startup capital of 100 billion dollars in the context of OBOR [3]. The One Belt denotes to the "Silk Road Economic Belt", a revival of the old land-based Silk Road which connected China to central Asia, the Middle East and Europe. So, it is also known as Modern Silk Road [4]. The One Road denotes to the " $21^{\text {st }}$ Century Maritime Silk Road" which planned to connect Asia, Africa, the Middle East and Europe. This is also known as Maritime Silk Road. The aim of the OBOR is to connect Asia, Europe and Africa through strengthening partnerships among the countries. China's imperial envoy Zhang Qian initiated the old Silk Road 2000 years ago which has been facilitated as a trade route to Arab and central Asia [5]. Since silk was one of the top most exports item of china at that time so this route is known as Silk Road. In 2013, president Xi Jinping declared to establish and revitalize the old Silk Road by establishing a connection among China, all parts of Asia, Europe and Africa through infrastructure development like railways and roads [6]. It is the largest economic platform of the world which will promote global economic growth through strengthening economic cooperation [7]. OBOR is working in two ways viz. Silk Road Economic Belt and $21^{\text {st }}$ Century Maritime Silk Road. The Silk Road Economic Belt consists of three routes connecting China to Europe, the Persian Gulf, the Mediterranean and the Indian Ocean [7]. On the other hand, the $21^{\text {st }}$ Century Maritime Silk Road is based on water ways among OBOR member countries. OBOR is a mega project which covers two-thirds of the global population and three-fourth of the energy resources [8]. Though some researchers thought that OBOR is an initiative to promote their meltdown economy by creating smooth global markets [9], it is portrayed to reshape the political and economic order of Asia by developing a network of cultural, political and trading corporation. The OBOR already got 65 countries as member under its initiative [10]. The importance of OBOR initiative cannot be ignored due to its active role on mutual peace and economic development. It connects Asian countries like Bangladesh, Brunei, Singapore, Sri Lanka, Cambodia, Myanmar, Maldives, Nepal, India, Sudan and Pakistan through seaports, oil and gas pipelines and economic corridors. It also finances for free trade economic zones and energy development projects in its member countries. The policy makers and scholars of US, Japan and India expressed their security threats in the OBOR regions due to the growing influence of OBOR in- 
itiative of China [11]. Though China considered it as propaganda against OBOR's peaceful journey, the benefit of the OBOR will be available for all the people of the world due to its peaceful natures like mutual cooperation, integration and interdependence. A multi-polar world will be established by proper implementation of OBOR through trends of harmony and peace.

The main purpose of this study is to answer the questions: 1) what are the implications of the One Belt One Road initiative? 2) what are the contexts of origin, strategies, opportunities and challenges of OBOR initiatives? and 3) Is the OBOR initiative enough for future global development? These questions lead the researcher team to explore implication of One Belt One Road initiative for global future development. The first section describes about the introduction of OBOR, second and third sections describes about methodology and systematic reviews of literature. Fourth and fifth section describes context of origin, strategy, opportunities, challenges and implications of OBOR for future global development. Final section concludes the article with some recommendations.

\section{Methodology}

\subsection{Research Design}

A conceptual framework is developed for implication of OBOR initiative for future global development through an extensive review of the literature [12]. The research is descriptive in nature based on some indicators of global economic development. The study mainly focuses on context of origin, strategy, opportunities and challenges of OBOR initiatives on the basis of business, economic, political, social and environmental aspects.

\subsection{Sources of Data}

Secondary sources have been extensively used related to implication of OBOR initiative, challenges and opportunities in the process of implementation of OBOR strategy and future global economic development. The latest information has been included for a better recommendation for implication of OBOR initiative.

\subsection{Search Strategy}

Data has been extensively searched from some renowned databases viz google scholar, a web of science, science direct, and Springer link website using important keywords like "one belt one road, economic belt, maritime silk road, OBOR, economic development, policy, strategy, regional development, global economic development, challenges, opportunities, security, geopolitics, and China" for securing authentic information [13]. The data collection and analysis for this study has been done during December 2017. Literature reviews are a significant part of the development of a field [14]. It offers the opportunity to synthesize and reflect on previous research, and thus providing secure grounding for the advancement of knowledge [15]. 


\subsection{Data Analysis}

Data is analyzed from different perspectives of One Belt One Road, challenges and opportunities for implementation, funding sources, involvement of partner countries, suitability of economic corridors, strategy for implementation and future global economic development.

\section{Review of Related Work}

Though OBOR is the revival of old Silk Road but it has a great impact on global economy through integration of a large part of the world under an umbrella. It extends its opportunity through developing a historical infrastructural development. It connects the world people through political, economic, and cultural interactions [16]. Though some scholars think that OBOR initiative is solely based on the implementation of Chinese "Go West" policy but still it has a tremendous impact on global economy [11] [17] [18]. Chinese authority has a largest influence on OBOR initiative because of an initiator and largest economy [19]. It also included the Digital Silk Road initiative for connecting the world digitally which is administered by the Cyberspace Administration of China. There is some geographically important place in China like Xinjiang as Core Area of the One Belt and Fujian as the "Core Area" for the "One Road" for implementing two mega projects under OBOR initiative [7] [20] [21]. Some other places like Qinghai, Gansu, Ningxia, and Shaanxi also important to connect China to central Asia through Economic Belt. The places like Sichuan, Chongqing, and Yunnan of China are also connects China to Central, South, and Southeast Asia through Economic Belt while Southeast Asia, South Asia, the Middle East, and Africa through Fujian, Jiangsu, Zhejiang, Guangdong, and Hainan of China [22]. Some scholar mentioned that OBOR initiative is the extension, enrichment, and amalgamation of some Chinese initiatives for promoting sluggish Chinese economy through maintaining national security, economic, business and international relations [7] [23] [24] [25]. According to PWC [26], the OBOR countries require at least USD 5 trillion for infrastructure development from 2016 to 2020 while according to Asian Development Bank, Asia require USD 8 trillion for infrastructure development by 2020 for connecting the partner of OBOR countries and getting full benefit from OBOR initiative [2] [27] [28]. Since most of the OBOR partners are developing countries so infrastructure development should be the top priority for global future development under OBOR initiative [29]. Another most important step should be taken to remove the constraints of trade and investment, reducing trade cost and motivating economic development [30]. Financial integration is one of the important goals of OBOR initiative which can be gained by encouraging monetary policy coordination, internalization of Renminbi (RMB) for trade and investment, motivating financial cooperation, creating regional financial institutions, strengthening cooperation for risk management, and encouraging regional mechanisms for managing financial risks [31] [32] [33]. Cultural exchanges can be happened through connecting people 
of OBOR partner countries, enhancing mutual understanding and nurturing more interactions among people [34]. Proper implementation of OBOR initiative can help to develop economy from China to central Asia, Europe and Africa. The summary of literature review is presented in Table 1.

Table 1. Recent studies on the OBOR initiative.

\begin{tabular}{|c|c|c|}
\hline Authors & Major issues/conclusions & Journal/source \\
\hline $\begin{array}{l}\text { Haiquan, } 2017 \\
\text { [35] }\end{array}$ & OBOR is a tool for enhancing China's open economy. & $\begin{array}{l}\text { Croatian International Relations } \\
\text { Review }\end{array}$ \\
\hline $\begin{array}{l}\text { Cheong, } 2017 \\
{[36]}\end{array}$ & $\begin{array}{l}\text { Focusing on economic assessment of OBOR. Pointed out some risks regarding } \\
\text { implementation. }\end{array}$ & $\begin{array}{l}\text { Journal of International } \\
\text { Logistics and Trade }\end{array}$ \\
\hline $\begin{array}{l}\text { Blanchard \& } \\
\text { Flint, } 2017[37]\end{array}$ & $\begin{array}{l}\text { Changing of world political paradigm and solving practical problems are main } \\
\text { consideration of OBOR. }\end{array}$ & Geopolitics \\
\hline Chung, 2017 [38] & $\begin{array}{l}\text { OBOR promotes the economic growth that underpins its domestic political stability in } \\
\text { China and other partner countries. }\end{array}$ & The Pacific Review \\
\hline Das, 2017 [39] & $\begin{array}{l}\text { OBOR initiative can solve the problem of over production capacity by exporting its } \\
\text { products to neighboring countries along the OBOR geographical region. }\end{array}$ & China Report \\
\hline $\begin{array}{l}\text { Du \& Zhang, } \\
2017[19]\end{array}$ & $\begin{array}{l}\text { China's overseas direct investment (ODI), especially whole or majority-ownership } \\
\text { mergers and acquisitions, rose significantly in the belt-road countries. }\end{array}$ & China Economic Review \\
\hline $\begin{array}{l}\text { Vangeli, } 2017 \\
{[40]}\end{array}$ & $\begin{array}{l}\text { OBOR initiative is the strong practical and normative link between China's domestic } \\
\text { development and its global orientation. }\end{array}$ & China \& World Economy \\
\hline Gabuev, 2017 & $\begin{array}{l}\text { International scholars have still debate on the nature of OBOR and major disputed } \\
\text { elements of strategy and set of random projects and priorities. }\end{array}$ & $\begin{array}{l}\text { The Journal of Contemporary } \\
\text { China Studies }\end{array}$ \\
\hline Yu, 2017 [33] & $\begin{array}{l}\text { The OBOR initiatives are a reflection of China's ascendance in the global arena, } \\
\text { economically, politically, and strategically. }\end{array}$ & Journal of Contemporary China \\
\hline $\begin{array}{l}\text { Haiquan, } 2017 \\
\text { [35] }\end{array}$ & $\begin{array}{l}\text { China needs to pay special attention to three issues, namely the supply of public } \\
\text { security goods, the interests of the United States and Russia, and the pivot of Pakistan, } \\
\text { besides developing its own strength. }\end{array}$ & $\begin{array}{l}\text { Croatian International Relations } \\
\text { Review }\end{array}$ \\
\hline Zeng, 2017 [24] & $\begin{array}{l}\text { Europe is a second order concern for China, and Europe only plays a marginalized role } \\
\text { in China's policy discussion. }\end{array}$ & $\begin{array}{l}\text { Journal of Common Market } \\
\text { Studies }\end{array}$ \\
\hline $\begin{array}{l}\text { Zeng, Wang, Qu, } \\
\& \mathrm{Li}, 2017[42]\end{array}$ & $\begin{array}{l}\text { Under China's Belt and Road (B \& R) initiative, Carat Canal, a potential new channel } \\
\text { of the Century Maritime Silk Road, will have a great impact on the shipping networks } \\
\text { and the evolution of hub ports. }\end{array}$ & $\begin{array}{l}\text { Transportation Research Part E: } \\
\text { Logistics and Transportation } \\
\text { Review }\end{array}$ \\
\hline $\begin{array}{l}\text { Wang, Ruet, \& } \\
\text { Richer, } 2017 \text { [43] }\end{array}$ & $\begin{array}{l}\text { The OBOR initiative has derived to epitomize China's growing significance in } \\
\text { international affairs, redesigning regional dynamics. }\end{array}$ & CEPN \\
\hline $\begin{array}{l}\text { Sidaway \& } \\
\text { Woon, } 2017[44]\end{array}$ & $\begin{array}{l}\text { The idea of a Silk Road(s) contains a history closely entangled with European } \\
\text { imperialism is skirted around in the contemporary reworking of the concept into } \\
\text { OBOR narratives. }\end{array}$ & Professional Geographer \\
\hline Jian, 2017 [45] & OBOR will form the backbone of future trade arrangements. & Al Jazeera Centre for Studies \\
\hline $\begin{array}{l}\text { Shapiro, } 2017 \\
{[46]}\end{array}$ & $\begin{array}{l}\text { OBOR includes peace and cooperation, openness and inclusiveness, mutual learning } \\
\text { and mutual benefit. }\end{array}$ & Geopolitics \\
\hline Aris, $2016[11]$ & $\begin{array}{l}\text { OBOR covers seven key regions viz. Africa, Central Asia, Eastern Europe, the Middle } \\
\text { East, Russia, South Asia and South-east Asia. }\end{array}$ & CSS Analyses in Security Policy \\
\hline
\end{tabular}




\section{Continued}

\begin{tabular}{ll}
\hline HKTDC (2017) & $\begin{array}{l}\text { Analysis of six economic corridors in the OBOR. Key areas of co-operation are policy, } \\
\text { finance and others. }\end{array}$ \\
Du (2016) [1] & $\begin{array}{l}\text { Compare the OBOR with the TPP, claiming the former to be the Chinese version of } \\
\text { globalization. }\end{array}$
\end{tabular}

Tian, $2016[48]$

OBOR is China's grand strategy encountering the US's TPP promotion or rebalancing in Asia.

Hsueh, 2016 [49] The OBOR would provide a great opportunity for the internationalization of the renminbi, since more trade and investment can be settled with renminbi.

Tian, Yu, \&

Zhang, 2016 [50]

Hali, Shukui, \&

Iqbal, 2015 [51]

Yang et al., 2016

[54]

Wolff, 2016 [8]

Xu, 2016 [52]

Xue, 2016 [53]

Yang et al., 2016

[54]

Haggai, 2016

[55]

Yuqing, 2016

[56]

Ferdinand, 2016

[57]

Grieger, 2016

[58]

Huang, 2016 [18]

EIU, 2015 [59]

Swaine, 2015

[60]

Zimmerman, 2015 [61]

Andrea, 2014 [4]
Outward FDI of China has become economically important to touch international investment with a $50 \%$ annual growth rate.

The OBOR has been perceived by Chinese planners and their well-wishers as a game changer for the entire region.

The rail way infrastructure can connect China to Europe as an important part of the OBOR initiative.

The Belt and Road initiative has common approaches to infrastructure development and regional cooperation by institutions, particularly the development banks.

China impetuses to reach well-adjusted regional development between coastal and inland regions, and places a priority on investment by OBOR Initiative.

China's foreign policy agenda will change significantly from "keeping a low profile" to "proactively and enterprisingly striving for achievements" as it implements the One Belt One Road (OBOR) strategy.

Some major challenges of OBOR are complex natural features, mismatched resources, shared ecological issues, and diverse socioeconomic conditions.

OBOR initiative has huge potential in promoting economic development in the partner nations.

China plans to achieve diplomatic, economic and political objectives through the AIIB through facilitating OBOR strategy and steering regional cooperation and integration.

China's foreign policy has moved from risk-averse caution to optimistic "dreaming" about a better world in which China will have recovered its rightful place.

The initiative is unprecedented in terms of China's financial engagement and the innovative network-based project design which is intended to contribute to a more inclusive global governance.

OBOR initiative aims to boost business and spread affluence across 60-plus countries with more than 4 billion people by construction of essential infrastructure and enhancing financial and trade links.

OBOR not only represents a renewed, stronger and better coordinated push to expand China's influence overseas, but it is also coupled with a domestic investment drive.

The One Belt, One Road initiative offers considerable potential in several economic, political, cultural, and strategic realms; it also presents many uncertainties and potential concerns.

OBOR has been designed to reshape the economic and political order in Central Asia and the Asian Pacific region by encouraging a network of trade routes, political cooperation, and cultural exchange.

China's OBOR initiative is based upon projects, not rules, supporting that China has made connectivity and infrastructure as the top priorities.
Hong Kong Trade Development Council

The Chinese Journal of Global

Governance

Voices

Journal of Contemporary East Asia Studies

China Economic Journal

Strategic Studies

Transportation Research Part E: Logistics and Transportation Review

German Development Institute

China Economic Review

Journal of Contemporary East Asia Studies

Ecosystem Health and Sustainability

World Journal of Social Sciences and Humanities

Chinese Political Science Review

International Affairs

EUROPEAN PARLEMENT Briefing

China Economic Review

The Economist Intelligence Unit Limited

China Leadership Monitor

Center on International Cooperation

Asian Review of World

Histories 
So many studies have been done by the researchers on OBOR issues but most of them are on the policy issues of OBOR initiatives [33] [62] [63]. Only few studies have been done on the background of the initiative, strategy, opportunities, challenges for implementation and implication for future of global development [55]. This study contributes to the ongoing debate on the positive and negative effect of OBOR initiative through exploring the context of origin, strategy, challenges, opportunities and implication for global future development. It may be the first study which explores the details of the OBOR initiative of China, linking to global effect and future development.

\section{OBOR Initiative: Context, Vision, Scope and Geographical Coverage}

\subsection{The Context}

OBOR initiative of china is the revival of old Silk Road. It is started by declaration of President Xi Jinping in 2013. It is one of the forms of China's Go West policy [17]. The root of OBOR initiative is largely related to the domestic economy of China. According to some scholars, China faces economic slowdown in recent days and the purpose of OBOR initiative is to promote the Chinese economy through creating a large market in the world particularly in the central Asia [3] [7] [64]. Cheap good manufacturing and exporting was the main strategy of China to capture international market in last three decades [1]. This strategy is no longer applicable in future days due to high carbon cost, labor intensive goods, and labor-intensive industries [11]. So, it is difficult for china to manage this transition from traditional pattern of development to new pattern of development for sustainable economic development [65], while china has already experienced to high sources of overseas direct investment. In the context of challenging situation, China feel for transformation of economic development pattern which requires the revival of Old Silk Road and forms One Belt One Road (Figure 1) which is recently known as Belt and Road initiative.

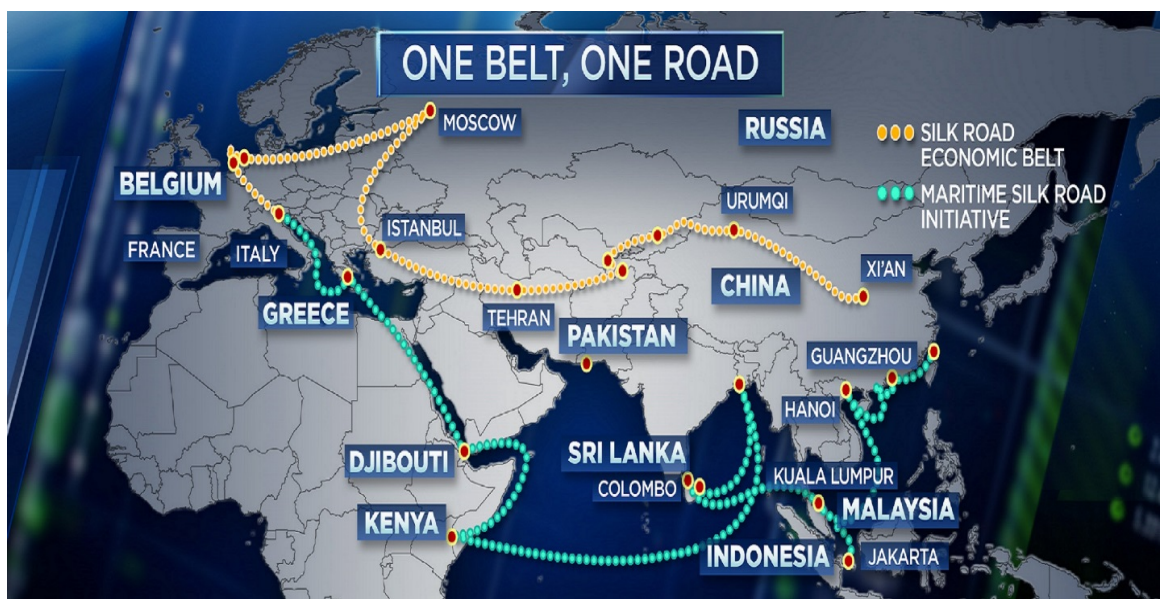

Source: Orissapost [66].

Figure 1. Map showing areas under one belt one road initiative. 


\subsection{The Vision}

The vision of OBOR is to connect the people over the world in terms of political dimensions, economic dimensions and cultural dimensions [55]. The major goals of OBOR initiative are achieving policy coordination among partners, building infrastructure for improving connectivity, promoting trades, motivating financial integration and improving relationships among the people of partner countries [11] [17]. Policy coordination also requires agreement between partners particularly free trade agreement in terms of custom, approval and inspection management [67]. The OBOR initiative already focuses on missing links in existing routes of transportation, port facilities, high quality railways, airways and sea ways, pipeline of oil and gas and telecommunication for enhancing connectivity among partner countries [68]. The Silk Road economic belt connects China to central Asia, Russia, central Asia and west Asia through Gulf Mediterranean Sea and China to Southeast Asia and south Asia through Indian Ocean. On the other hand, the $21^{\text {st }}$ Century maritime Silk Road connects china to Europe and Africa through South China Sea and Indian Ocean [69].

\subsection{The Scope}

The scope of OBOR is so wide and ambitious. OBOR initiative is trying to touches almost all fields of development through its two mega and historical projects viz Silk Road Economic Belt and the $21^{\text {st }}$ Century Maritime Silk Road (Table 2).

The OBOR initiative mainly focuses infrastructure development, trend of multipolar globe, economic globalization, political coordination, cultural diversification and advanced IT adoption for achieving policy coordination, improving

Table 2. Major partners and events of OBOR.

\begin{tabular}{|c|c|}
\hline 65 Countries & Connects 65 countries and estimated 4.4 billion people 65 Countries \\
\hline Accounted & Accounted. \\
\hline $30 \%$ of GDP & Accounted for over $63 \%$ of world population and $30 \%$ of GDP. \\
\hline 3 Rounds & $\begin{array}{l}\text { The } 3^{\text {rd }} \text { round of China's opening up after development of Special } \\
\text { Economic Zones and accession to WTO. }\end{array}$ \\
\hline $70+$ Countries & $\begin{array}{l}\text { Over } 70+\text { countries and international organizations have signed } \\
\text { cooperation agreements with China. }\end{array}$ \\
\hline 5 Key Areas & $\begin{array}{l}\text { The } 5 \text { key areas of cooperation are: policy coordination, facilities } \\
\text { connectivity, trade, financial integration and people-to-people ties. }\end{array}$ \\
\hline $\begin{array}{l}6 \text { Economic } \\
\text { Corridors }\end{array}$ & $\begin{array}{l}\text { Set-up } 6 \text { economic cooperation corridors: China Pakistan, New Eurasia } \\
\text { Land Bridge, China-Mongolia-Russia, China-Central Asia-West Asia, } \\
\text { China Indochina Peninsula, Bangladesh-China-India-Myanmar. }\end{array}$ \\
\hline US\$ 953 Billion & $\begin{array}{l}\text { China's trade value with B \& R countries reached US } \$ 953 \text { billion in } \\
2016,25.7 \% \text { of China's total trade } 8158 \text {. }\end{array}$ \\
\hline 8158 Contracts & 8158 Contracts were signed by Chinese enterprises in 61 countries in 2016. \\
\hline EXIM Bank of China & It had started financing over 1000 projects in 49 OBOR countries in 2016. \\
\hline
\end{tabular}


facilities, enhancing connectivity, stimulating financial integration and better relationship among people [16] [53]. It also focuses on economic flows, investment, resource allocation and market integration, motivating nations for policy coordination through regional cooperation and encouraging open, comprehensive and balanced regional economic cooperation [33] [36] [70] [71].

\subsection{Geographical Coverage}

The aim of OBOR initiative is to connect the world from Asia to Europe and Africa through its two mega projects by road ways, airways and sea ways [51]. It intends to connect about 60 countries across Asia, Europe and Africa (Figure 2). One of the major objectives of China behind the OBOR initiative is to implement Go West policy [58].

\subsection{The Financial Support}

Since OBOR is a mega and historical project so it requires huge amount of finance. US $\$ 40$ billion Silk Road fund is already declared by the Chinese government which will support for implementing OBOR strategy [2]. Some funding bodies like china Investment Corporation, Export-Import bank of China, China Development Bank, and the State Administration of Foreign Exchange have already allocated the fund in 2015 (Table 3) [2]. The fund will use for developing infrastructure and industrial projects for improving connectivity among OBOR partners. Infrastructure development directly focuses on roads, railways, sea ports and airports. The Asian Infrastructure Investment Bank (AIIB) was launched in 2014 especially dedicated for dealing the financial matter of OBOR. AIIB already got US\$ 100 billon initial capital for dealing the matter of OBOR

The Belt and Road Initiative: Six Economic Corridors Spanning Asia, Europe and Africa

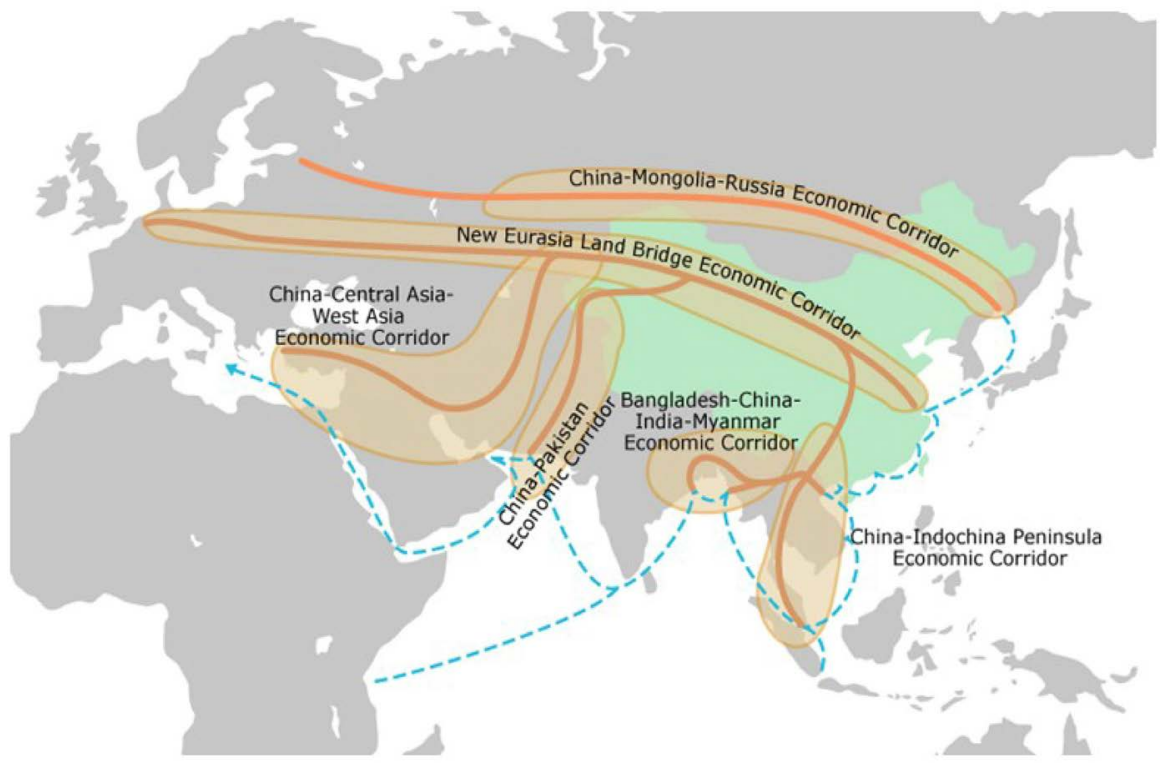

Source: HKTDC [25].

Figure 2. Economic corridors of one belt one road. 
Table 3. The funding mechanism of OBOR initiative.

\begin{tabular}{cccc}
\hline & \multicolumn{3}{c}{ Funding mechanism (US\$ billion) } \\
\cline { 2 - 4 } Institutions & $\begin{array}{c}\text { Authorized } \\
\text { capital size }\end{array}$ & $\begin{array}{c}\text { Recent lending } \\
\text { per year }\end{array}$ & $\begin{array}{c}\text { Possible lending per } \\
\text { year by early 2020s }\end{array}$ \\
\hline Multilateral Development Banks & & & $10-15$ \\
Asian Infrastructure Investment Bank & 100 & 1.7 & $5-7$ \\
New Development Bank & 100 & $2-1.5$ & $2-3$ \\
Silk Road Fund & 40 & four" banks in 2016 \\
Commercial Banks & An estimated US\$90 billion annual lending by the "big \\
Policy Banks & - & 15 (2015) & - \\
China Development Bank (CDB) & - & $24(2015)$ & - \\
Export-Import Bank of China & - &
\end{tabular}

Source: He [27], Chua [2].

particularly for building construction and infrastructure [3]. The estimated value of MOUs signed is reached RMB 1890 billion. China Development Bank and the Export-Import Bank of China are committed to provide loan RMB 250 billion and RMB 130 billion for OBOR initiative projects respectively [27]. The financial institution of China is also motivated to increase overseas fund up to RMB 300 billion for OBOR. Only in 2016 China achieved US\$ 126 billion new contracts from OBOR partner countries which will deliver high growth rate of $36.5 \%$ YoY [2]. China Development Bank also committed to provide investment for more than 900 projects which covers infrastructure, coal and gas, electricity, mining, telecommunication and agriculture sector of about 60 countries [72]. It will help to reduce the gap between demand and supply for spending an infrastructure development.

\section{Implication for Future of Global Development}

The philosophy of OBOR is not to threat the other nations but bring a sustainable economic growth by combining some key development initiatives [8]. OBOR can influence the Chinese major policy, development strategy, foreign relations and investment in future which will be helpful for regional and global economic development [36]. It also helps to connect its partners in terms of physical, political, cultural, financial, and psychological interactions [70]. It is actually a way for future economic development through developing infrastructure from Asia to Africa and Europe and promoting economic flows among all partner countries. The six economic corridors of OBOR initiative connects the geopolitically important part from Southeast Asia, Central Asia, South Asia and Europe which helps to promote the business, economics, and influence of china over other countries [55]. China already made success to make land links from Southeast China to Southeast Asia which was intended target of Asian Development Bank and others for making land connection [3]. It is happened because of making economic corridor of OBOR initiative. Another corridor connects China from 
Kunming to Vietnam, Laos, and Myanmar. The economy of central Asia is very smaller than China. Due to OBOR initiative, China will be the top supplier of manufactured goods to Central Asia as well as top consumer of agricultural output and resources of Central Asia [4]. Some geopolitical places would be economically viable after proper implementation of OBOR strategy.

\section{Challenges Related to Implementation of OBOR}

1) Absolute size and scale of understanding in case of infrastructure development is one of the major challenges for OBOR initiative [11]. Private funding is necessary alongside with the funding from Chinese government and AIIB for accomplishment of the infrastructure of OBOR initiative [59] [73].

2) A huge amount infrastructure development requires enough time to accomplish. No infrastructure will be effective for economic return before full accomplishment [59]. Since china is now facing an economic slowdown, challenge of finance from local government and bad debt so in near future funding for infrastructure development may face difficulties and under pressure [73]. So, it is necessary to invite some potential financial partner to improve the situation.

3) The infrastructure of OBOR is not enough for bring proper economic benefits from OBOR initiative [74]. The infrastructure of partner countries should be considered during infrastructure development for effectiveness of OBOR initiative. Some advanced countries have no requirement for infrastructure development but some developing countries require enough infrastructure to connect with other partners.

4) Geography and topography of all partner countries are not same. It is very difficult to make smooth transportation way connecting high topography to low topographical region. Long distance, high and low topography, densely forest areas and high mountain should be considered during planning and construction of land routes.

5) Geopolitical challenges are the major challenge for implementation of OBOR initiative. Relationship between India-Pakistan is not good and favor to OBOR initiative [59]. Since China-Pakistan corridor passes through Pakistan controlled Kashmir which is extremely opposed by the Indian government [35]. Dispute between Russia and Ukraine, civil wars in Syria, Iraq and Afghanistan are not favorable for OBOR initiative. Some other partner countries are suffering from political instability, and sanctions, corruption, expropriation and inefficiencies which affect the success of OBOR initiatives [22].

6) Security challenges are the major challenges for partner countries. Some scholars think that it is very difficult to manage the internal and external national security of partner countries [20] [35]. In some cases, it may be influenced by Chinese military or navy.

\section{Conclusion and Recommendation}

The study analyzes the suitability of OBOR for future of global development in 
terms of economic sustainability, political stability and cultural exchange. The study argues that OBOR initiative has a great potential for future of global development. It also analyzes the context of origin, vision, strategy, challenges and opportunities of OBOR initiative considering its applicability for global development. It also argues that China has a great influence on the OBOR initiative as an initiator and encouraging China's Go-West policy at all but it has a good impact on the economy of its partner as a whole. The article finds out some major challenges of OBOR like absolute size and scale, large infrastructure development, various geography and topography, geographical challenges and security challenges within the region. It suggests that strong coordination among partners of OBOR is necessary to get full fruits of OBOR through supportive law, policy, rules and regulations, proper strategy implementation, transparent procurement system, sincere consideration on political, financial, environmental and social factors. This study contributes to the ongoing debate on the positive and negative effect of OBOR initiative through exploring the context of origin, strategy, challenges, opportunities and implication for global future development.

\section{References}

[1] Du, M.M. (2016) China's “One Belt, One Road” Initiative: Context, Focus, Institutions, and Implications. The Chinese Journal of Global Governance, 2, 30-43. https://doi.org/10.1163/23525207-12340014

[2] Chua, A.C. (2017) One Belt One Road and Opportunities. http://www.centerforfinancialstability.org/research/Chua_OneBeltOneRoad_7_6_1 7.pdf

[3] AIIB (2016) Asian Infrastructure Investment Bank. Global Governance, 22, 11-26. http://www.aiib.org/

[4] Andrea, A.J. (2014) The Silk Road in World History: A Review Essay. Asian Review of World Histories, 2, 105-127. https://doi.org/10.12773/arwh.2014.2.1.105

[5] Van Hout, M.C. and Bingham, T. (2013) "Surfing the Silk Road": A Study of Users' experiences. International Journal of Drug Policy, 24, 524-529.

https://doi.org/10.1016/j.drugpo.2013.08.011

[6] Ramasamy, B., Yeung, M. and Laforet, S. (2012) China's Outward Foreign Direct Investment: Location Choice and Firm Ownership. Journal of World Business, 47, 17-25. https://doi.org/10.1016/j.jwb.2010.10.016

[7] Sauvant, K.P. and Chen, V.Z. (2014) China's Regulatory Framework for Outward Foreign Direct Investment. China Economic Journal, 7, 141-163. https://doi.org/10.1080/17538963.2013.874072

[8] Wolff, P. (2016) China's "Belt and Road" Initiative-Challenges and Opportunities. German Development Institute, Bonn.

[9] Sheu, J.B. and Kundu, T. (2017) Forecasting Time-Varying Logistics Distribution Flows in the One Belt-One Road Strategic Context. Transportation Research Part E: Logistics and Transportation Review, in Press. https://doi.org/10.1016/j.tre.2017.03.003

[10] Ouyang, L. (2017) One Belt, One Road and China's Evolution in Foreign Policy and Regional Leadership. Global Commerce Scholar Thesis, University of Virginia, 
Charlottesville.

[11] Aris, S. (2016) One Belt, One Road: China’s Vision of "Connectivity”. CSS Analyses in Security Policy, 195, 1-4.

[12] Sarker, M.N.I. (2017) An Introduction to Agricultural Anthropology: Pathway to Sustainable Agriculture. Journal of Sociology and Anthropology, 1, 47-52.

[13] Sarker, M.N.I. and Jie, Z. (2017) Social Security for Vulnerable Groups in Bangladesh on Government Perspective: Contribution of Research Leader. Journal of Public Policy and Administration, 1, 1-9.

[14] Liu, C., Kuang, Y., Huang, N. and Liu, X. (2014) An Empirical Research on Evaluation of Low-Carbon Economy in Guangdong Province, China: Based on "Production, Life and Environment". Low Carbon Economy, 5, 139-152. https://doi.org/10.4236/lce.2014.54015

[15] Yang, B. (2017) China's Low-Carbon Economy Development and Carbon Finance Market Supervision Mechanism. Low Carbon Economy, 8, Article ID: 97105. https://doi.org/10.4236/lce.2017.84008

[16] Uberoi, P. (2016) Problems and Prospects of the BCIM Economic Corridor. China Report, 52, 19-44. https://doi.org/10.1177/0009445515613868

[17] Huang, Y. (2016) Understanding China's Belt \& Road Initiative: Motivation, Framework and Assessment. China Economic Review, 40, 314-321. https://doi.org/10.1016/j.chieco.2016.07.007

[18] Mishra, R. (2016) Asian Infrastructure Investment Bank: An Assessment. India Quarterly: A Journal of International Affairs, 72, 163-176. https://doi.org/10.1177/0974928416643582

[19] Du, J. and Zhang, Y. (2017) Does One Belt One Road Initiative Promote Chinese Overseas Direct Investment? China Economic Review, 1-61.

[20] Pop, I.I. (2016) Strengths and Challenges of China's “One Belt, One Road” Initiative. http://www.cgsrs.org

[21] Xu, L., Fan, X., Wang, W., Xu, L., Duan, Y. and Shi, R. (2017) Renewable and Sustainable Energy of Xinjiang and Development Strategy of Node Areas in the "Silk Road Economic Belt.” Renewable and Sustainable Energy Reviews, 79, 274-285. https://doi.org/10.1016/j.rser.2017.05.031

[22] Djankov, S. and Miner, S. (2016) China's Belt and Road Initiative: Motives, Scope and Challenges. Peterson Institute for International Economics Briefing, PIE Briefing 16-2, 1-35. https://piie.com/system/files/documents/piieb16-2_1.pdf

[23] Krukowska, M. (2016) China's One Belt, One Road Strategy and Its Implication for the Global World Order. International Business and Global Economy, 35, 157-168.

[24] Zeng, J. (2017) Does Europe Matter? The Role of Europe in Chinese Narratives of "One Belt One Road" and "New Type of Great Power Relations." Journal of Common Market Studies, 55, 1162-1176. https://doi.org/10.1111/jcms.12535

[25] HKTDC (2017) Interpreting the Belt and Road Initiative. HKTDC (Hong Kong Trade Development Council) Research, 268.

[26] PWC (2016) Opportunities in Emerging Market China: Belt \& Road, PPP.

[27] He, T. (2017) One Belt, One Road: How Will Partners Profit? Brinknews. http://www.brinknews.com/asia/one-belt-one-road-how-will-partners-profit/

[28] Fallon, T. (2015) The New Silk Road: Xi Jinping's Grand Strategy for Eurasia. American Foreign Policy Interests, 37, 140-147. https://doi.org/10.1080/10803920.2015.1056682 
[29] Gray, K. and Murphy, C.N. (2015) Introduction: Rising Powers and the Future of Global Governance. Third World Quarterly, 34, 183-193. https://doi.org/10.1080/01436597.2013.775778

[30] Duan, F., Ji, Q., Liu, B.Y. and Fan, Y. (2018) Energy Investment Risk Assessment for Nations along China's Belt \& Road Initiative. Journal of Cleaner Production, 170, 535-547. https://doi.org/10.1016/j.jclepro.2017.09.152

[31] Kaplan, Y. (2017) China's OBOR as a Geo-Functional Institutionalist Project. Baltic Journal of European Studies, 7, 7-23. https://doi.org/10.1515/bjes-2017-0002

[32] Ejdys, J. (2017) New Silk Road-A Weak or a Strong Signal? Procedia Engineering, 182, 182-188. https://doi.org/10.1016/j.proeng.2017.03.159

[33] Yu, H. (2017) Motivation behind China's “One Belt, One Road” Initiatives and Establishment of the Asian Infrastructure Investment Bank. Journal of Contemporary China, 26, 353-368. https://doi.org/10.1080/10670564.2016.1245894

[34] Muttarak, R. (2017) Potential Implications of China's “One Belt, One Road” Strategies on Chinese International Migration.

[35] Haiquan, L. (2017) The Security Challenges of the "One Belt, One Road" Initiative and China's Choices. Croatian International Relations Review, 23, 129-147. https://doi.org/10.1515/cirr-2017-0010

[36] Chen, S. (2017) Regional Responses to China's Maritime Silk Road Initiative in Southeast Asia. Journal of Contemporary China, 27, 344-361.

https://doi.org/10.1080/10670564.2018.1410960

[37] Blanchard, J.M.F. and Flint, C. (2017) The Geopolitics of China's Maritime Silk Road Initiative. Geopolitics, 22, 223-245. https://doi.org/10.1080/14650045.2017.1291503

[38] Chung, C. (2017) What Are the Strategic and Economic Implications for South Asia of China's Maritime Silk Road initiative? The Pacific Review, 31, 1-18.

[39] Das, K.C. (2017) The Making of One Belt, One Road and Dilemmas in South Asia. China Report, 53, 125-142. https://doi.org/10.1177/0009445517696624

[40] Vangeli, A. (2017) China's Engagement with the Sixteen Countries of Central, East and Southeast Europe under the Belt and Road Initiative. China \& World Economy, 25, 101-124. https://doi.org/10.1111/cwe.12216

[41] Gabuev, A. (2017) Crouching Bear, Hidden Dragon: "One Belt One Road" and Chinese-Russian Jostling for Power in Central Asia. The Journal of Contemporary China Studies, 5, 61-78.

[42] Zeng, Q., Wang, G.W.Y., Qu, C. and Li, K.X. (2017) Impact of the Carat Canal on the Evolution of Hub Ports under China's Belt and Road Initiative. Transportation Research Part E: Logistics and Transportation Review, 30, 1-12. https://doi.org/10.1016/j.tre.2017.05.009

[43] Wang, X., Ruet, J. and Richer, X. (2017) One Belt One Road and the Reconfiguration of China-EU Relations. CEPN Working Papers 2017-04, Centre d'Economie de l'Université de Paris Nord, Paris. http://www.e-ir.info/2017/03/26/one-belt-one-road-and-the-history-of-the-maritim e-silk-route/

[44] Sidaway, J.D. and Woon, C.Y. (2017) Chinese Narratives on "One Belt, One Road" in Geopolitical and Imperial Contexts. Professional Geographer, 69, 591-603. https://doi.org/10.1080/00330124.2017.1288576

[45] Jian, W. (2017) “One Belt One Road”: A Vision for the Future of China-Middle East Relations. 
http://studies.aljazeera.net/en/reports/2017/05/belt-road-vision-future-china-middl e-east-relations-170509102227548.html

[46] Shapiro, J.L. (2017) One Belt, One Road, No Dice. Geopolitics Geopolitical Futures, 1-7. https://geopoliticalfutures.com

[47] HKTDC (2016) The Belt and Road Initiative. Hktbc, 6, 1-6.

[48] Tian, J. (2016) “One Belt and One Road”: Connecting China and the World. Voices, 1-3.

https://www.mckinsey.com/industries/capital-projects-and-infrastructure/our-insig hts/one-belt-and-one-road-connecting-china-and-the-world

[49] Hsueh, C. (2016) Taiwan's Perspective on China's “One Belt, One Road” Strategy. Journal of Contemporary East Asia Studies, 5, 37-60. https://doi.org/10.1080/24761028.2016.11869096

[50] Tian, W., Yu, M. and Zhang, F. (2016) The Exceptional Performance of Chinese outward Direct Investment Firms. China Economic Journal, 9, 209-219. https://doi.org/10.1080/17538963.2016.1172783

[51] Hali, S.M., Shukui, T. and Iqbal, S. (2015) One Belt and One Road: Impact on China-Pakistan Economic Corridor. Strategic Studies, 34-35, 147-164.

[52] Xu, H. (2016) Domestic Railroad Infrastructure and Exports: Evidence from the Silk Route. China Economic Review, 41, 129-147. https://doi.org/10.1016/j.chieco.2016.09.005

[53] Xue, L. (2016) China's Foreign Policy Decision-Making Mechanism and “One Belt One Road” Strategy. Journal of Contemporary East Asia Studies, 5, 23-35. https://doi.org/10.1080/24761028.2016.11869095

[54] Yang, D., Cai, J., Hull, V., Wang, K., Tsang, Y.-P. and Liu, J. (2016) New Road for Telecoupling Global Prosperity and Ecological Sustainability. Ecosystem Health and Sustainability, 2, e01242. https://doi.org/10.1002/ehs2.1242

[55] Haggai, K. (2016) One Belt One Road Strategy in China and Economic Development in the Concerning Countries. World Journal of Social Sciences and Humanities, 2, 10-14.

[56] Yuqing, X. (2016) The Asian Infrastructure Investment Bank and China's Role in Regional Economic Governance. Chinese Political Science Review, 1, 25-36.

[57] Ferdinand, P. (2016) Westward ho-The China Dream and "One Belt, One Road": Chinese Foreign Policy under Xi Jinping. International Affairs, 92, 941-957. https://doi.org/10.1111/1468-2346.12660

[58] Grieger, G. (2016) One Belt, One Road (OBOR): China’s Regional Integration Initiative (EPRS (European Parliamentary Research Service) No. PE 586.608) European Parlement Briefing.

[59] EIU (2015) Prospects and Challenges on China's “One Belt, One Road”: A Risk Assessment Report. http://www.eiu.com

[60] Swaine, M.D. (2015) Chinese Views and Commentary on the "One Belt, One Road" Initiative. China Leadership Monitor, 47, 3-27.

https://www.hoover.org/sites/default/files/research/docs/clm47ms.pdf

[61] Zimmerman, T. (2015) The New Silk Roads: China, the U.S., and the Future of Central Asia. Center on International Cooperation, New York, 1-26.

[62] Kudaibergenova, D.T. (2017) "My Silk Road to You": Re-Imagining Routes, Roads, and Geography in Contemporary Art of "Central Asia." Journal of Eurasian Studies, 8, 31-43. https://doi.org/10.1016/j.euras.2016.11.007 
[63] Hu, R., Liu, R. and Hu, N. (2017) China's Belt and Road Initiative from a Global Health Perspective. The Lancet Global Health, 5, e752-e753. https://doi.org/10.1016/S2214-109X(17)30250-4

[64] Zhou, W. and Esteban, M. (2018) Beyond Balancing: China's Approach towards the Belt and Road Initiative. Journal of Contemporary China, 27, 1-15. https://doi.org/10.1080/10670564.2018.1433476

[65] Carey, R., Prizzon, A., Jiajun, X. and Humphrey, C. (2015) Multilateral Development Banks in the 21st Century Three Perspectives on China and the Asian Infrastructure Investment Bank. Overseas Development Institute, London, 20.

[66] Orissapost (2017) Russia Wants India to Join OBOR Initiative. http://www.orissapost.com/russia-wants-india-to-join-obor-initiative/

[67] Chin, H., Lau, F., He, W. and Cheung, T. (2015) The Silk Road Economic Belt and the 21st Century Maritime Silk Road. Fung Business Intelligence Centre, New York.

[68] Shao, Z.Z., Ma, Z.J., Sheu, J.B. and Gao, H.O. (2017) Evaluation of Large-Scale Transnational High-Speed Railway Construction Priority in the Belt and Road Region. Transportation Research Part E: Logistics and Transportation Review, 1-18. https://doi.org/10.1016/j.tre.2017.07.007

[69] Bhoothalingam, R. (2016) The Silk Road as a Global Brand. China Report, 52, 45-52. https://doi.org/10.1177/0009445515613869

[70] Khattak, A.K. and Khalid, I. (2013) China's One Belt One Road Initiative: Towards Mutual Peace \& Development. Journal of Research Society of Pakistan, 54, 1-20.

[71] Cheng, L.K. (2016) Three Questions on China's "Belt and Road Initiative." China Economic Review, 40, 309-313. https://doi.org/10.1016/j.chieco.2016.07.008

[72] European Political Strategy Centre (2015) The Asian Infrastructure Investment Bank. EPSC Strategic Notes.

https://ec.europa.eu/epsc/publications/strategic-notes/asian-infrastructure-investme nt-bank_en

[73] He, H. (2016) Key Challenges and Countermeasures with Railway Accessibility along the Silk Road. Engineering, 2, 288-291. https://doi.org/10.1016/J.ENG.2016.03.017

[74] Zhou, Q. (2015) China's New International Development Initiative-Asian Infrastructure Investment Bank: Opportunities and Challenges. Asia-Pacific Finance and Development Center, Beijing, 1-21.

http://devpolicy.org/2015-Australasian-aid-conference/presentations/Zhou-Qiangw u.pdf 